This item was submitted to Loughborough's Research Repository by the author.

Items in Figshare are protected by copyright, with all rights reserved, unless otherwise indicated.

\title{
Distribution and characteristics of large landslides in a fault zone: A case study of the NE Qinghai-Tibet Plateau
}

PLEASE CITE THE PUBLISHED VERSION

https://doi.org/10.1016/j.geomorph.2021.107592

PUBLISHER

Elsevier

VERSION

AM (Accepted Manuscript)

\section{PUBLISHER STATEMENT}

This paper was accepted for publication in the journal Geomorphology and the definitive published version is available at https://doi.org/10.1016/j.geomorph.2021.107592

\section{LICENCE}

CC BY-NC-ND 4.0

\section{REPOSITORY RECORD}

Qi, Tianjun, Xingmin Meng, Feng Qin, Yi Zhang, Yan Zhao, Wei Shi, Guan Chen, et al.. 2021. "Distribution and Characteristics of Large Landslides in a Fault Zone: A Case Study of the NE Qinghai-tibet Plateau". Loughborough University. https://hdl.handle.net/2134/14035052.v1. 
1 Characteristics of large-scale landslides in a fault zone and a

2 conceptual model of regional geomorphic evolution: a case study of the

3 NE Qinghai-Tibet Plateau

4 Tianjun $\mathrm{Qi}^{2,3}$, Xingmin Meng ${ }^{* 1,2,3}$, Feng Qin ${ }^{1,2,3}$, Yan Zhao ${ }^{1,2,3}$, Wei Shi ${ }^{2,3}$,

5 Guan Chen ${ }^{1,2,3}$, Yi Zhang ${ }^{1,2,3}$, Yajun $\mathrm{Li}^{1,2,3}$, Dongxia Yue ${ }^{1,2,3}$, Xiaojun $\mathrm{Su}^{2,3}$,

$6 \quad$ Fuyun $\mathrm{Guo}^{4}$, Runqiang Zeng ${ }^{1,2,3}$, Tom Dijkstra ${ }^{5}$

$7 \quad{ }^{1}$ School of Earth Sciences, Lanzhou University, Lanzhou 730000, China

$8 \quad{ }^{2}$ College of Earth and Environmental Sciences, MOE Key Laboratory of Western

9 China's Environmental Systems, Lanzhou University, Lanzhou 730000, China

${ }^{3}$ Gansu Technology Innovation Centre for Environmental Geology and Geohazard

11 Prevention, Lanzhou 730000, China

${ }^{4}$ Geological Environment Monitoring Institute of Gansu Province, Lanzhou 730050,

China

${ }^{5}$ School of Architecture, Building and Civil Engineering, Loughborough University, Loughborough, LE11 3TU, UK

*Corresponding author:

School of Earth Sciences, Lanzhou University, Lanzhou 730000, China

College of Earth and Environmental Sciences, MOE Key Laboratory of Western

China's Environmental Systems, Lanzhou University, Lanzhou 730000, China

Gansu Technology Innovation Centre for Environmental Geology and Geohazard

Prevention, Lanzhou 730000, China 
Rm 914 Guanyun Building, 222 Tianshui South Road

Lanzhou, 730000, P. R. China

E-mail: xmmeng@lzu.edu.cn

\section{Highlights}

(1) Based on the inventory of large-scale landslides in the middle reaches of Bailong River and the interpretation of four UAV images, the characteristics of large-scale landslides in the region are comprehensively summarized for the first time.

(2) The control effect of fault zone on large-scale landslide is explained. Fault zones play an important role in spatial distribution, morphological characteristics and activity of large-scale landslides.

(3) A conceptual model of geomorphic evolution under the coupling effect of river and fault zone is proposed. This model may be universal in the northeastern margin of Qinghai-Tibet Plateau.

\section{Abstract}

The NW-SE-striking fault zone in the Bailong River Basin in the northeastern margin of the Qinghai-Tibet Plateau have the most densely distributed, large complex landslides in China. However, the failure of large complex landslides along the fault zone and the causes of their complex geomorphic characteristics are unclear. The purpose of this study was to explore the relationship between the fault zone and the spatial distribution, direction of movement, and geomorphic characteristics of 
large landslides. We inventoried 29 large landslides in the middle reaches of the Bailong River and described their characteristics. Statistical analysis revealed differences in the spatial relationship between the faults and landslides of different scales. Almost all of the landslide bodies with an area $>1 \mathrm{~km} 2$ are distributed on the faults; in addition, the strike of the faults was found to constrain the direction of movement of the landslides to the WNW-ESE direction. Statistical results show that the cross sections of landslides in the study area are asymmetric arc, corresponding to which there are significant differences in the geomorphological characteristics of the north and south sides of landslides. The geometric characteristics, physical properties (i.e., material weakness) of the fault zone and rapid uplift of the hanging wall were responsible for the asymmetric shape of landslide cross sections and the geomorphic difference. We present a conceptual model based on the relationship between the fault zone and landslides, which facilitates an improved understanding of the relationship between the fault zone and landslide evolution.

Keywords Bailong River; large-scale landslides; fault zone; conceptual model

\section{Introduction}

Large landslides are widely distributed in orogenic belts and plateau margins with strong tectonic activity (Hovius et al., 1997; Jr, 1998; Korup, 
2005; Dortch et al., 2009; Sato and Harp, 2009; Carlini et al., 2016; Pánek et al., 2019). Morphometric analysis, air photo interpretation, and airborne Lidar have been used to determine the geomorphic imprints of large landslides on hillslopes in such regions (Korup, 2006; Haneberg et al., 2009; Guzzetti et al., 2012; Pánek and Klimeš, 2016). In an orogenic belt, the formation, evolution, geomorphic characteristics and spatial distribution of large landslides are closely related to regional tectonic activity and local structure (Keefer, 1984; Pedrazzini et al., 2016; Borrelli and Gullà, 2017; Carlini et al., 2017; Cui et al., 2018). Previous research results have revealed that the control of landslides by tectonics is complex across time and space. In the rapidly-uplifted orogenic belt, on a long-time scale, there is a common slope threshold angle which when exceeded results in the slope gradient being extensively modified by bedrock landslides which restrict the growth of the mountains (Whipple et al., 1999; Montgomery, 2001; Montgomery and Brandon, 2002; Larsen and Montgomery, 2012; Roering, 2012; Li et al., 2014). On a short-time scale, violent tectonic activity, such as large earthquakes, is the main factor inducing large landslides (Keefer, 1984; Keefer, 1994; Owen et al., 2008). For landslides controlled by tectonic structure, the influence of the local geological framework has attracted substantial research attention. The spatial geometry of tectonic foliations, including faults, folds, joints and cleavage, and the anisotropy of lithology, have a profound impact on the 
type, location and frequency of landslides (Kellogg, 2001; Brideau et al., 2009; Alexander and Formichi, 2010; Norini et al., 2010; Borrelli et al., 2014; Břežný and Pánek, 2017; Görüm, 2018). There are large differences in the nature of this influence in different regions (Margielewski, 2006). Compared with the general foliation structure, landslides are more likely to occur around the fault zone because of the more intensive foliation and loss of strength of the rock mass (Collettini et al., 2009). Sendir and Yilmaz (2002) showed that in the North Anatolian fault zone, jointing and faulting, steep topography, fluvial incisions, and heavy rainfall were important influences on the occurrence of landslides; Bois et al. (2008) demonstrated that inherited fault zones at depth play a major role on the style of gravitational deformation patterns; Demir (2019) used ArcGIS to evaluate the susceptibility of the North Anatolian fault zone to landslides, and the results indicated that distance to streams, roads and faults determined the occurrence and distribution of landslides; Zhang et al. (2018) used InSAR technology in the fault zone of the Zhouqu region in China to identify 11 active earthflows, 19 active landslides with deformation rates exceeding $100 \mathrm{~mm} /$ year, and 20 new instabilities. However, examples of the comprehensive analysis of fault zones and landslides are relatively rare, and the relationship between complex fault zones and landslide development and evolution has not been fully explained.

$$
\text { The Bailong River Basin is located in the northeastern margin of the }
$$


Qinghai-Tibet Plateau. The compression of the North China plate during the Indosinian period and the uplift and expansion of the Qinghai-Tibet Plateau in the Himalayan period resulted in it becoming one of the most active and complex tectonic regions on Earth (Zhang et al., 2004; Molnar and Stock, 2009; Zheng et al., 2016). Rapid crustal uplift and erosion during the Cenozoic have resulted in the formation of the extremely steep topography of the region (Zhang et al., 2013). This provides a favorable condition for the development of large complex landslides in this area. According to recent studies, the large complex landslides have been reactivated many times in the past (Jiang et al., 2016); a large number of secondary landslides (including the earthflow, loess landslide, translational landslide and rockfall) are present for the landslide complexes (Zhang et al., 2018); the landslide materials include fractured rocks, gravel-soil complex and loess (Huang et al., 2013); the deformation of landslide mass is regulated by multiple internal shear planes and viscous deformation, and the depth of sliding surface is between 8 and $50 \mathrm{~m}$ (Yang et al., 2013); fault fracture zones are where landslide creep deformation occurred (Si et al., 2017). Analyses by InSAR technology revealed that earthflows and landslides exhibited seasonal variations and accelerated deformation as a result of earthquakes in the Zhouqu area (Zhang et al., 2018). However, these studies did not address the control of the fault zone on the distribution, orientation, and geomorphic characteristics of landslides. The extensive 
spatial development of the thrust-strike-slip fault zone in the northeastern margin of the Qinghai- Tibet Plateau (Yuan et al., 2004) means that knowledge of the control of fault zones on large landslides will aid understanding of landform evolution and inform disaster prevention strategies.

The term "landslide" refers to a hillside process under the action of gravity which results in significant erosion and transportation of slope materials (Crozier et al., 2010). Varnes (1978) and Hungr et al. (2014) produced a detailed classification of landslide types, which shows that most of the landslides in the Bailong River Basin are complex landslides. In contrast to typical rock landslides in the orogenic belt (Borrelli and Gullà, 2017; Cui et al., 2018), the ancient landslides in the area are characterized by a high and steep side scarp, and they have developed lots of secondary landslides on the ancient landslide bodies. Secondary earthflows are mainly developed in the middle of the ancient landslides, while secondary translational landslides and rockfalls are distributed on both sides of the earthflows. Zhang et al. (2018) monitored the deformation of landslides in the area and showed that the deformation rate of earthflow varied in different parts of the complex landslide body. Compared with the secondary landslides distributed on the north and south sides, the earthflow in the central part has a faster deformation rate, with the range of $101-103$ $\mathrm{mm} /$ year (Wasowski and Bovenga, 2014). For simplicity, we henceforth 
use the term "landslide" to refer to a complex landslide.

The intention of this study was to understand the relationship between tectonic structures and landslides and to inform disaster prevention policies. The specific aims are as follows: (i) to provide an inventory of large landslides in the middle reaches of the Bailong River Basin; (ii) to describe the geomorphic characteristics and the spatial distribution of large landslides in the area; and (iii) to determine the relationship between the geomorphic characteristics and evolutionary processes of large landslides and fault zones.

\section{Study area}

The Bailong River Basin is located at the intersection of three major geomorphic units: the Qinghai-Tibet Plateau, the Qinling Mountains, and the Chinese Loess Plateau (Fig. 1). Intense tectonic activity and fluvial incision have produced a terrain characterized by high mountains and deeply incised valleys. The topography in the study area is steep in the south and north and low in the centre; the altitudinal range is $3636-1220$ $\mathrm{m}$, with a relative height difference of $2416 \mathrm{~m}$. Silurian and Permian limestone are respectively exposed in the high-altitude areas in the north and south parts of the study area. Fluvial erosion and extreme rainfall events related to climate change have resulted in frequent major landslides, rockfalls and debris flow disasters (Tang et al., 2011; Dijkstra et al., 2012; 
Cui et al., 2013; Guo et al., 2020). In addition, the widely distributed fault zones are considered to play an important role in the occurrence of geological disasters (Yang et al., 2013). Due to its location in the southern margin of the Chinese Loess Plateau, loess deposits of varying thickness occur in the study area. The second and third tributaries of the Yangtze River, Bailong River and Min River occur in the area, with annual average discharges of $10.8 \times 109 \mathrm{~m} 3$ and $60.7 \times 107 \mathrm{~m} 3$, respectively. Due to the frequent landslides, river blocking events are common, the most recent being the Yahuokou landslide on July 16, 2019. The area has a high population density, and on the one hand, the development of landslides provides construction site and agricultural land for the inhabitants, but on the other hand, the landslides are a huge threat to human safety and the local economy.

The climate of the region is transitional between the subtropical and temperate zones in the Northern Hemisphere. The annual average temperature exceeds $14{ }^{\circ} \mathrm{C}$, and the annual average rainfall is $450-800 \mathrm{~mm}$; the rainfall has a pronounced seasonality and is concentrated in June to October, occurring in the form of heavy rainfall events or rainstorms.

\section{Tectonics and geology}

From the perspective of the regional tectonics, the study area is located in the western Qinling-Songpan tectonic node which is situated in the 
centre of the Asian continent (Fig. 2). During the completion of the major amalgamation of the Asian continent, and with interactions with the tectonic systems of the Alps and Himalayas, the Pacific Ocean and CircumSiberia, the node was formed as a result of the conjunction and transformation of different orogens and massifs that constitute the Asian continent. The tectonic node represents a key tectonic domain spanning the area of the conjunction and transformation of the east-west-striking Central Orogenic System, the approximately southnorth- striking Sichuan-YunnanHelan tectonic belt, and the Qinghai- Tibet Plateau, which formed during the Mesozoic and Cenozoic (Zhang et al., 2004). During the Cenozoic, the tectonic activity of the Altun Mountains, Minshan Mountains, Longmen Mountains, and the Sichuan Yunnan Plateau have accelerated, resulting in uplift, growth and compression in the northeast direction during the expansion of the Qinghai-Tibet Plateau. These quasi-contemporaneous events resulted in the expansion of the Qinghai-Tibet Plateau to the surrounding area by $\sim 8 \mathrm{Ma}$ via a series of thrust faults, fold deformation and left lateral strike-slip faults, as well as the accompanying mountain uplift and basin subsidence. These processes are also responsible for the modern environmental configuration in and around the Qinghai-Tibet Plateau (Zhang et al., 2006).

Three roughly parallel fault zones $(\mathrm{F} 1, \mathrm{~F} 2, \mathrm{~F} 3)$ occur in the study area (Fig. 1); they are distributed along the NW-SE direction and in the 
southeast, they are deflected to the ENE direction. Due to the effect of compressive stress during the thrust-slipping process, the lithology of the fault zone is highly fragmented, and some of the rocks have been argillized and transformed to fine-grained fault gouge (Fig. 3) (Shen et al., 2014). The depression provides favorable conditions for the development of earthflows. From the depression left by rock exposure and erosion, it can be determined that the widths of the three fault zones from south to north are $863 \mathrm{~m}, 1664 \mathrm{~m}$, and $1996 \mathrm{~m}$, respectively (Fig. 4A). During the investigation, a large number of fault planes were observed in the study area (Fig. 5). Measurements indicate that the occurrence of the exposed fault planes in the study area are consistent, with dip directions of $205-208^{\circ}$ and dip angles of $40-45^{\circ}$. In the process of fault zone convergence towards the ENE, the dip angle increases to $73^{\circ}$ with dip directions of $119-172^{\circ}$. Yu et al. (2012) conducted geomorphological and chronological analyses for the Pingding-Huama fault and found that the reverse slip rate of the fault zone is $0.49 \pm 0.08$ to $1.15 \pm 0.28 \mathrm{~mm} / \mathrm{a}$ and the sinistral slip rate is $0.51 \pm$ $0.13 \mathrm{~mm} / \mathrm{a}$ since the late Quaternary; Chen et al. (2012) monitored characteristics of the crustal deformation and the current activity of the main faults on the northeast margin of Baryan-Har block (located in the northeast of Qinghai-Tibet Plateau, Sichuan-Gansu border area) by using GPS data. The results revealed that the Diebu-Bailongjiang fault zone was dominated by sinistral strike slip and thrust, with a strike slip rate of 1.1 
$\mathrm{mm} / \mathrm{a}$ and a compression rate of $2.0 \mathrm{~mm} / \mathrm{a}$.

The lithology in the study area consists of the interbedding of Silurian and Permian limestone with gray-black fault zone material (Fig. 6A), together with an interlayer of metamorphic phyllite (Fig. 6B). The lowlying part of the area is covered by Quaternary loess deposits, and based on an exposed loess profile the thickness of the loess reaches 3-4 m (Fig. $6 C)$.

\section{Materials and methods}

A detailed landslide map is essential for studying the spatial distribution and the evolution of landslides, and for evaluating landslide susceptibility and hence the risk avoidance of landslide disasters (Guzzetti et al., 2012). Traditional survey methods have gradually been replaced by the use of high-resolution remote sensing images (Galli et al., 2008), aerial photos and DEM interpretation (Haneberg et al., 2009), and semi-automated and automated methods of landslide identification have also become popular (Mckean, 2004; Tarolli et al., 2012). For small areas, unmanned aerial vehicles (UAV) are valuable due to their low-cost, convenience and high precision. However, the landslide data obtained using these methods needs to be verified by traditional methods, and therefore high-resolution image interpretation combined with traditional field-based verification can provide an optimum combination of efficiency and accuracy. In this study we downloaded Google Earth images (0.5-m resolution) in November 
2019, and we used Google Earth software to identify and interpret landslides across the selected area. In addition, the interpreted data were verified and supplemented by field investigations. Finally, ArcGIS 10.2 software was used for landslide mapping.

In order to better understand the characteristics of typical landslides in the fault zone, a Dajiang UAV was used to photograph four landslides, with an image resolution of up to $5-10 \mathrm{~cm}$. These remote sensing images combined with the results of field investigations were used to determine the surface features of each landslide. In addition, in order to compare the geomorphic features of the landslides, a DEM with a 5-m resolution was used to obtain the landslide cross-sections, slope and height difference of the landslides.

\section{Landslide inventory and description}

\subsection{Landslides inventory and mapping}

To date, no comprehensive landslide inventory is available for the middle reaches of the Bailong River. The previous landslide list includes location information of several landslides and the morphological characteristics of secondary landslides (Bai et al., 2013; Chen et al., 2014); however, the large landslides are not fully catalogued. We obtained the initial complex landslide boundary by interpreting a Google Earth remote 
sensing image, combined with field correction, and finally inventoried 29 large landslides. The location and morphometric parameters of the landslides are presented in Fig. 1 and Table 1. The largest landslide has an area of $5.6 \mathrm{~km} 2$ and the smallest an area of $0.07 \mathrm{~km} 2$; the average landslide area is $1.33 \mathrm{~km} 2$. The total area of landslides is $38.4 \mathrm{~km} 2$, representing $21 \%$ of the total study area. Currently, the landslide classification methods of Varnes (1978) and Hungr et al. (2014) are used worldwide, according to their classification, most types of landslides in the study area are large complex landslides.

\subsection{Distribution and characteristics of landslides}

\subsubsection{Spatial distribution of landslides}

Faults are an important factor affecting the spatial distribution of landslides. In addition to providing structural planes favorable for landslide development, the loss of strength of the rock mass caused by fault formation and activity is closely related to the distance to the fault (Alexander and Formichi, 2010). The statistical results show that there is a clustering between the landslide area and the distance to faults (Fig. 7A). Most of the landslides with an area $<1 \mathrm{~km} 2$ have no fault passing through and they are distributed between the faults. Almost all the landslides with an area $>1 \mathrm{~km} 2$ are close to a fault, and the larger the area of the landslide, the greater the influence of the fault. Lithology is another important factor affecting the distribution of landslides. There is a distinct relationship 
between the landslide area and lithology (Fig. 7A). All of the landslides with an area $>3 \mathrm{~km} 2$ are distributed in the contact zone of limestone and phyllite (or slate). The interface between the two types of lithology is often a fault plane (Fig. 1), and the 11 smallest landslides are all distributed in areas of carbonaceous slate and phyllite (i.e., with a weak lithology). The faults and lithology undoubtedly control the distribution of landslides in the area. Faults and large-scale landslides are the most closely related, while lithology has a greater influence on the distribution of small-scale landslides.

\subsubsection{Landslide characteristics}

Slope, aspect ratio (length: width), and height difference reflect the morphological characteristics of landslides. The relationships between slope, aspect ratio and landslide area vary widely for small-scale landslides but become increasingly similar with increasing landslide area (Fig. 7B and C). In addition, there is a positive correlation between landslide height difference and landslide area (Fig. 7C). Combining these trends with the relationship of landslides to faults and lithology, we suggest that the differences between small-scale landslides are more substantial, while the characteristics of large-scale landslides, which are closely related to faults, are more similar. In order to determine the influence of structure on landslides, we carried out a detailed field geomorphological investigation of the landslides along the faults. 

the following. First, they are generally rectangular and elongated, with two high and steep side scarps extending almost parallel to each other (Fig. 4A). Fault planes are generally exposed on the north side scarp (Fig. 5) while the main scarp is often covered with thick loess (Fig. 4B). Second, the materials comprising the landslide mass are varied, including fault gouge, loess, and coarse gravels formed by rockfalls. gray-black fault gouge, the middle part mixed with several meters of loess, and the upper part is covered by gravels (Fig. 4C). Rockfalls tend to occur landslide bodies, and the type and spatial distribution of these secondary available monitoring results, the activity of these secondary landslides is 
faster deformation rate than the secondary landslides distributed on the north and south sides, ranging from 101 to $103 \mathrm{~mm} /$ year (Wasowski and Bovenga, 2014). The asymmetric arc of the cross section of the landslide corresponds to the geomorphological difference between the north and the south sides of the landslide (Fig. 9). Cross sections of the large landslides from south to north were obtained using a $5 \mathrm{~m}$ DEM, and the lowest points of the cross sections are located at the same position of the horizontal axis. The results show that the cross sections of the landslide in the study area have the form of an asymmetric arc, with the south side scarp being shorter and steeper, and the north side scarp being longer and more gently sloping. In addition, the larger the landslide scale, the more pronounced the asymmetry.

We analyzed the relationship between the movement direction of landslides and the fault strike in the study area, in order to assess the effect of the fault zone on landslide movement. The results show that the landslide movement has a symmetrical distribution, along the WNWESE direction, which is roughly consistent with the NW-SE direction of the fault zone strike (Fig. 10).

\subsection{Landslide case studies}

UAV images and field investigations were used to reveal the geomorphic features of four representative fault landslides (Fig. 11), which 
are described below.

\subsubsection{The Yahuokou landslide (YL)}

This landslide is the reactivation of an older landslide which started on July 16, 2019 and slow deformation is still continuing (Fig. 11A). The road and the buildings at the toe of the landslide were destroyed, and part of the Min River was blocked, reducing its width from $26 \mathrm{~m}$ to $6 \mathrm{~m}$. The slow rate of movement of the landslide enabled the local inhabitants to be evacuated and there were few casualties. The new landslide is in the form of a narrow strip, $1477 \mathrm{~m}$ in length and with an average width of $100 \mathrm{~m}$ and average slope of $27^{\circ}$. The two sides of the old landslide are almost parallel, and numerous new and old rockfalls are distributed on the south side. On the north side (except for the uppermost part), there is a rockfall which mainly covers cultivated land and buildings. The material composition of the landslide mass is complex and there is some degree of stratification (Fig. 4C). Boulders produced by rockfalls have accumulated on the surface and both sides of the landslide mass, and there is an underlying loess layer (Fig. 6C). Beneath the loess layer and rockfall deposits, the fault gouge produced by fault compression is mainly grayblack in color and hard when dry; the sliding surface of the slope occurs mainly within this layer. The activity of the landslide may be controlled by fluvial erosion at the front and by fault activity. 


\subsubsection{The Daxiaowan landslide (DL)}

The landslide has the form of a long strip, with the two side scarps straight and almost parallel (Fig. 11B). The length is $3742 \mathrm{~m}$, the average width is $968 \mathrm{~m}$, and the area is $3.1 \mathrm{~km} 2$. The elevation range is 1369-2671 $\mathrm{m}$, with a relative height difference of $1302 \mathrm{~m}$, and the average slope is $30.4^{\circ}$. The landslide is characterized by multistage sliding, from the head to the toe, and two secondary scarps are developed on the landslide body. The surface of the first stage is uneven, the middle part is convex, and the 404 lower part has a vegetation coverage of almost $100 \%$, which indicates a 405 low level of activity and that this part has remained stable for a long period. gradually decreases in height from northwest to southeast. The surface of 408 the landslide is covered by abundant coarse gravel with maximum 409 diameters of up to $23 \mathrm{~m}$. The rear of the main scarp of the third stage is arcshaped with a height of $7 \mathrm{~m}$; analysis of remote sensing images and field investigation indicated that this stage is the most active. Loess deposits and 412 cultivated land are distributed on the north side of the landslide and there 413 are no residential buildings. The active path of this section of the landslide 414 is close to the south scarp, and the landslide material has filled most of the river channels. The activity is affected by failure of slope toe by river 
the strongest; the upper part of the landslide is the least active.

\subsubsection{The Zhongpai landslide (ZL)}

This landslide is influenced by several faults and it is the most complex landslide in the study area, being significant different from other three landslides (Fig. 11C). It has an irregular funnel shape with a length of 4560 $\mathrm{m}$. The width of the main scarp is up to $1552 \mathrm{~m}$; however, the frontal moving area of the landslide is only $44 \mathrm{~m}$ wide. The area is $5.16 \mathrm{~km} 2$, the average slope is $22.5^{\circ}$, and the maximum slope is $78.7^{\circ}$. The shape of the main scarp is irregular and there are substantial changes in height. The elevation decreases from $2705 \mathrm{~m}$ to $2372 \mathrm{~m}$ from south to north, and numerous small rockfalls are developed on the south side. The side scarp is not straight, the north side scarp is V-shaped, the upper section is mainly a fault plane, and the lower section is cut by three faults. The south side scarp is also cut by faults, has an irregular shape, and has more rockfalls in the middle and upper parts. Like the DL landslide, the ZL landslide can be divided into three stages. The first stage is occupied by cultivated land in the south and is covered by natural vegetation in the north. The second stage is almost entirely occupied by cultivated land and residential buildings, which indicates that it is has been stable for a relatively long time. The third stage is the front part of the landslide and is blocked by mountains at the front; it is the most active part of the landslide. 

$\mathrm{m}$, width of $821 \mathrm{~m}$, and area of $2.0 \mathrm{~km} 2$. The elevation range is $2217-1295$

$442 \mathrm{~m}$, with a height difference of $922 \mathrm{~m}$; the average slope is $23.5^{\circ}$ (Fig. 11D). The shape of the main scarp is irregular and covered by loess. There is no obvious scarp exposed on the north side, and the height of the south scarp 445 reaches up to $203 \mathrm{~m}$. There is a very large accumulation of gravels in the river channel at the toe of the landslide mass. Because of the rapid rate of material accumulation in the front of the landslide, the river channel has a pronounced curve. Within the entire region, XL has one of the highest 449 frequencies of landslides which block the Bailong River.

\section{Results and discussion}

452

\subsection{Relationship between landslides and faults}

Although it is recognized that tectonic structures control the 454 455 development of landslides (Brideau et al., 2009; Alexander and Formichi, 2010), it is unclear how this control is manifested in different tectonic 457 characteristics of the landslides in the Bailongiiang fault zone, the structure 458 has a large influence on the location, direction of movement, and 459 geomorphic characteristics of the landslides. The relationship between 460 structure and landslides enabled us to produce a three-dimensional model 
of the landslides in the fault zone (Fig. 12).

There are significant differences between landslide of different scales and distance to fault. Most of the larger landslides are crossed by faults, while the smaller landslides are distributed between the faults. The close relationship between the larger landslides and faults depends on long-term tectonic process. The slate and phyllite in the footwall of the fault are transformed to gray-black weak gouge after being subjected to strong compression by thrust nappe and strike slip processes. Previous observations showed that the average residual shear strength values of the weak gouge (effective angles of internal friction) are likely to be lower than approximately $13^{\circ}$ to $15^{\circ}$ (Zhang et al., 2018) and that rainfall, earthquakes and fluvial erosion of the slope toe are the main factors inducing slope instability. The development of earthflows exploits geological weaknesses in the fault controlled belt of low-grade metamorphic rocks.

To a certain extent, the faults influence the direction of movement of these landslides, which is related to the linear characteristics of the fault zone. We found that the symmetrical landslide movement along the WNWESE direction in the study area was completely controlled by the fault strike (Fig. 10). Notably, the movement direction of the landslides is constrained by the fault plane distributed on both sides of the fault zone. There is no doubt that the giant landslides developed in the fault zone have experienced a long period of evolution (inferring from the thick loess layer 
483

484

485

covered by landslide surface), and the landslide area is continuously expanding with uplift and fluvial erosion. When the width of the landslide is consistent with the width of the fault zone, under the influence of the faults on both sides of the fault zone, the direction of movement of the landslide conforms entirely with the strike of the fault zone.

The complex geomorphic characteristics of large landslides in the fault zone of the Bailong River Basin are different from those of bedrock landslides controlled by faults or joints, and there are many secondary landslides with different types and levels of activity. The middle part of large landslides is mainly characterized by slow-moving earthflows. The types of secondary landslide on the north and south side scarps are quite different: rockfalls mainly occur on the south side, while loess landslides and translational landslides occur mainly on the north side. Corresponding to their geomorphic differences, the cross section of the north and south sides also exhibits an asymmetric shape. We associate this geomorphic property with the geometry, material composition and activity characteristics of the fault zone. The soft fault gouge widely distributed in the fault zone is the material basis for the development of earthflows. Zhang et al.'s (2018) study of the Suoertou landslide showed that the activity of these earthflows and landslides varies seasonally and that accelerated deformation occurred following the Wenchuan earthquake in 2008. Quaternary loess and the contact surface between the bedrock and 
505

506

507

508

509

510

511

512

513

514

515

the fault gouge respectively provide the material and structural basis for the development of loess landslides and translational landslides on the north side. The loess has macropore structure and a large number of vertical fractures, which are the dominant paths for water infiltration. Consequently, loess landslide and translational landslide are developed on the north side scarp of the landslides taking bedrock as water resisting layer under the action of rainfall. On the premise that the long-term rapid erosion of earthflow provides a free face for the development of secondary landslide on both sides. The existing data show that the average thrust rate of faults in the area in the Late Quaternary was $0.49-1.15 \mathrm{~mm} / \mathrm{year}$ (Yu et al., 2012), and that the rapid uplift of the hanging wall of the fault is likely to be an important factor for the development of rockfalls on the south side. Meanwhile, the impact of long-term erosion of the secondary earthflow on the stability of the south scarp is also noteworthy. As the occurrence of the fault zone dips to the southwest, and the weak fault gouge is located under the bedrock of the south scarp, the instability of the side scarp will eventually occur with the continuous erosion of the fault zone material and the thrusting of the hanging wall.

\subsection{A conceptual model for large landslides controlled by fault zone}

Tectonic structures are the main internal factor controlling the development of large-scale landslides in orogenic belts, and the nature of 
527 its influence depends on the geological environment (Pánek et al., 528 2019).We used the relationship between the materials, structural 529 characteristics, and activity of the fault zone and the spatial distribution 530 and geomorphic characteristics of large-scale landslides to develop a 531 conceptual model for the development and evolution of fault zones and 532 landslides (Fig. 13). The weak fault gouge distributed within the fault zone 533 promotes the development of secondary earthflows in the middle of the 534 large landslide body. Various types of secondary landslide are development 535 on the north and south sides of the landslides. This spatial distribution is 536 entirely controlled by the structure. From the perspective of tectonic

537 evolution, the fault zone, as a geological body composed of weak materials, 538 has the material and energy conditions for landslide development after the 539 crust is uplifted and continuous fluvial undercutting occurs so that the slope 540 reaches a critical angle. Therefore, rainfall, earthquakes, and the 541 accumulation of rockfall material result in the depression of the fault zone 542 developing earthflows, which further induce translational landslides on the 543 north side scarp. In the process of continuing material erosion and the 544 thrusting of the hanging wall in the fault zone, secondary landslides 545 dominated by rockfalls develop on the south side scarp of the landslide.

\section{Conclusion}

We have conducted a comprehensive investigation and inventory of 
large landslides in the central Bailong River Basin in the NE Qinghai-Tibet Plateau, with the aim of determining how the fault zone controls the landslides in the area. The results show that the distribution, direction of movement and geomorphic features of landslides are controlled by fault zones.

The spatial distribution of landslides is related to the distance to the fault and by the lithology. Landslides with an area $>1 \mathrm{~km} 2$ are closely related to faults, and faults are distributed within these landslide bodies. The reduction of the structural integrity of the rock mass caused by the compression of thrust faults is the main factor leading to the development of giant landslides in the fault zone. The movement direction of landslides is symmetrically distributed along the WNW-ESE direction, which is entirely constrained by the fault strike. The weak material formed along the fault zone promotes the development of secondary earthflows, and the fault planes on both sides of the fault zone restrict the movement direction of the landslide; this constraint is enhanced with increasing landslide area. The asymmetric arc shape of the cross section of the landslide, and the difference in geomorphic characteristics between the north and south sides of the landslide body, are typical characteristics of the landslides in the study area. This difference depends on the geometric characteristics and tectonic activity of the fault zone. The secondary translational landslides on the north side scarp of the landslide mostly develop along the fault plane 
571 inclined to the southwest, while the secondary rockfalls of the south side 572 scarp are related to the uplift of the hanging wall of the fault and the erosion 573 of materials in the fracture zone.

574 Based on the distribution and characteristics of landslides and their 575 relationship with the fault zone, we propose a conceptual model of 576 landslides in the study area. A large number of thrust-slip faults have 577 developed during the process of thrusting in the northeastern margin of the 578 Qinghai-Tibet Plateau, and these fault zones may contain similar landslide 579 development patterns as we have observed in the Bailong River Basin.

\section{Declaration of competing interest}

We declare that we have no financial and personal relationships with other people or organizations that can inappropriately influence our work, there is no professional or other personal interest of any nature or kind in any product, service and/or company that could be construed as influencing the position presented in, or the review of, the manuscript entitled.

\section{Acknowledgements}

This work was funded by the National Key Research and Development Program of China (Grant No. 2017YFC1501005), Science and Technology 
593

594

595

596

597

598

599

600

601

602

603

604

605

606

607

608

609

610

611

612

613

614

615

616

617

618

619

620

621

622

623

624

625

626

627

628

629

for International S\&T Cooperation Projects of Gansu Province (No. 2018-

0204-GJC-0043), Fundamental Research Funds for the Central

Universities (lzujbky-2018-46). We thank Jan Bloemendal for his comments which has improved this paper and for English language corrections.

\section{References}

Alexander, D., Formichi, R., 2010. Tectonic causes of landslides. Earth Surface Processes \& Landforms 18, 311-338.

Bai, S., Xu, Q., Wang, J., Zhou, P., 2013. Pre-conditioning factors and susceptibility assessments of Wenchuan earthquake landslide at the Zhouqu segment of Bailongjiang basin, China. J. Geol. Soc. India 82, 575-582.

Bois, T., Bouissou, S., Guglielmi, Y., 2008. Influence of major inherited faults zones on gravitational slope deformation: a two-dimensional physical modelling of the $\mathrm{La}$ Clapière area (Southern French Alps). Earth \& Planetary Science Letters 272, 709719.

Borrelli, L., Gullà, G., 2017. Tectonic constraints on a deep-seated rock slide in weathered crystalline rocks. Geomorphology 290, 288-316.

Borrelli, L., Antronico, L., Gullà, G., Sorriso-Valvo, G.M., 2014. Geology, geomorphology and dynamics of the 15 February 2010 Maierato landslide (Calabria, Italy). Geomorphology, 208, 50-73.

Břežný, M., Pánek, T., 2017. Deep-seated landslides affecting monoclinal flysch morphostructure: Evaluation of LiDAR-derived topography of the highest range of the Czech Carpathians. Geomorphology 285, 44-57.

Brideau, M.A., Yan, M., Stead, D., 2009. The role of tectonic damage and brittle rock fracture in the development of large rock slope failures. Geomorphology 103, 3049.

Carlini, M., Chelli, A., Vescovi, P., Artoni, A., Clemenzi, L., Tellini, C., Torelli, L., 2016. Tectonic control on the development and distribution of large landslides in the Northern Apennines (Italy). Geomorphology 253, 425-437.

Carlini, M., Chelli, A., Francese, R., Giacomelli, S., Giorgi, M., Quagliarini, A., Carpena, A., Tellini, C., 2017. Landslides types controlled by tectonics-induced evolution of valley slopes (Northern Apennines, Italy). Landslides 4, 1-14.

Chen, Y., Ren, J., Meng, G., Yang, P., Zhang, J., Su, X., 2012. Analysis of modern activity of major faults in northeast margin of Baryan-Har block. Journal of Geodesy and Geodynamics 32, 27-30 (in Chinese).

Chen, G., Meng, X., Tan, L., Zhang, F., Qiao, L., 2014. Comparison and combination 
of different models for optimal landslide susceptibility zonation. Q J Eng. Geol. Hydroge. 47, 283-306.

Collettini, C., Niemeijer, A., Viti, C., Marone, C., 2009. Fault zone fabric and fault weakness. Nature 462, 907-910.

Crozier, M.J., Gutiérrez, F., Soldati, M., Audemard, F., BăLteanu, D., 2010. Deciphering the effect of climate change on landslide activity: a review. Geomorphology 124, 260-267.

Cui, P., Zhou, G., Zhu, X., Zhang, J., 2013. Scale amplification of natural debris flows caused by cascading landslide dam failures. Geomorphology 182, 173-189.

Cui, S., Pei, X., Huang, R., 2018. Effects of geological and tectonic characteristics on the earthquake-triggered Daguangbao landslide, China. Landslides 15, 649-667.

Demir, G., 2019. GIS-based landslide susceptibility mapping for a part of the North Anatolian Fault Zone between Readiye and Koyulhisar (Turkey). Catena 183, 1-12.

Dijkstra, et al., 2012. Geomorphic controls and debris flows - the 2010 Zhouqu disaster, China. Proceedings of the 11th International Symposium on Landslides (ISL) and the 2nd North American Symposium on Landslides.

Dortch, J.M., Owen, L.A., Haneberg, W.C., Caffee, M.W., Dietsch, C., Kamp, U., 2009. Nature and timing of large landslides in the Himalaya and Transhimalaya of northern India. Quat. Sci. Rev. 28, 1037-1054.

Galli, M., Ardizzone, F., Cardinali, M., Reichenbach, N.F.P., 2008. Comparing landslide inventory maps. Geomorphology 94, 268-289.

Görüm, T., 2018. Tectonic, topographic and rock-type influences on large landslides at the northern margin of the Anatolian Plateau. Landslides 16, 333-346.

Guo, C., Zhang, Y., Li, X., Ren, S., Yang, Z., Wu, R., Jin, J., 2020. Reactivation of giant Jiangdingya ancient landslide in Zhouqu County, Gansu Province, China. Landslides 17, 179-190.

Guzzetti, F., Mondini, A.C., Cardinali, M., Fiorucci, F., Santangelo, M., Chang, K.T., 2012. Landslide inventory maps: New tools for an old problem. Earth Sci. Rev. 112, 42-66.

Haneberg, W.C., Cole, W.F., Kasali, G., 2009. High-resolution lidar-based landslide hazard mapping and modeling, UCSF Parnassus Campus, San Francisco, USA. Bulletin of Engineering Geology \& the Environment 68, 263-276.

Hovius, N., Stark, C.P., Allen, P.A., 1997. Sediment flux from a mountain belt derived by landslide mapping. Geology 25, 231-234.

Huang, X., Yang, W., Zhang, C., Shen, J., Liu, T., 2013. The formation mechanism of Suoertou landslide in Pingding-Huama fault zone, southern Gansu. Geological Bulletin of China 32, 1936-1942 (in Chinese).

Hungr, O., Leroueil, S., Picarelli, L., 2014. The Varnes classification of landslide types, an update. Landslides 11, 167-194.

Jiang, S., Wen, B., Li, Z., Zhao, C., 2016. An analysis of the activity features of the Suoertou landslide in Zhouqu county of Gansu. Hydrogeology \& Engineering Geology 43, 69-92.

Jr, J.F.S., 1998. Slope failure and denudation in the western Himalaya. Geomorphology 26, 81-105. 
Keefer, D.K., 1984. Landslides caused by earthquakes. Geol. Soc. Am. Bull. 95, 406421.

Keefer, D.K., 1994. The importance of earthquake-induced landslides to long term slope erosion and slope-failure hazards in seismically active regions. Geomorphology 10, 265-284.

Kellogg, K.S., 2001. Tectonic controls on a large landslide complex: Williams Fork Mountains near Dillon, Colorado. Geomorphology 41, 355-368.

Korup, O., 2005. Distribution of landslides in southwest New Zealand. Landslides 2, 43-51.

Korup, O., 2006. Effects of large deep-seated landslides on hillslope morphology, western Southern Alps, New Zealand. J. Geophys. Res. 111, 1-18.

Larsen, I.J., Montgomery, D.R., 2012. Landslide erosion coupled to tectonics and river incision. Nat. Geosci. 5, 468-473.

Larsen, I.J., Montgomery, D.R., Korup, O., 2010. Landslide erosion controlled by hillslope material. Nat. Geosci. 3, 247-251.

Li, Y., Zhou, R., Zhao, G., Li, H., Su, D., Ding, H., Yan, Z., Yan, L., Yun, K.,Ma, C., 2014. Tectonic uplift and landslides triggered by the Wenchuan earthquake and constraints on orogenic growth: a case study from Hongchun Gully, Longmen Mountains, Sichuan, China. Quat. Int. 349, 142-152.

Margielewski,W., 2006. Structural control and types of movements of rockmass in anisotropic rocks: Case studies in the Polish Flysch Carpathians. Geomorphology 77, 47-68.

Mckean, J., 2004. Objective landslide detection and surface morphology mapping using high-resolution airborne laser altimetry. Geomorphology 57, 331-351.

Molnar, P., Stock, J.M., 2009. Slowing of India's convergence with Eurasia since $20 \mathrm{Ma}$ and its implications for Tibetan mantle dynamics. Tectonics 28, 1-11.

Montgomery, D.R., 2001. Slope distributions, threshold hillslopes, and steady-state topography. Am. J. Sci. 301, 432-454.

Montgomery, D.R., Brandon, M.T., 2002. Topographic controls on erosion rates in tectonically active mountain ranges. Earth Planet. Sci. Lett. 201, 0-489.

Norini, G., Capra, L., Borselli, L., Zuniga, F.R., Solari, L., Sarocchi, D., 2010. Large scale landslides triggered by Quaternary tectonics in the Acambay graben, Mexico. Earth Surface Processes \& Landforms 35, 1445-1455.

Owen, L.A., Kamp, U., Khattak, G.A., Harp, E.L., Keefer, D.K., Bauer, M.A., 2008. Landslides triggered by the 8 October 2005 Kashmir earthquake. Geomorphology 94, 1-9.

Pánek, T., Klimeš, J., 2016. Temporal behavior of deep-seated gravitational slope deformations: a review. Earth Sci. Rev. 156, 14-38.

Pánek, T., Břežný, M., Kapustová, V., Lenart, J., Chalupa, V., 2019. Large landslides and deep-seated gravitational slope deformations in the Czech Flysch Carpathians: New LiDAR-based inventory. Geomorphology 346, 0-17.

Pedrazzini, A., Humair, F., Jaboyedoff, M., Tonini, M., 2016. Characterisation and spatial distribution of gravitational slope deformation in the Upper Rhone catchment (Western Swiss Alps). Landslides 13, 259-277. 
Roering, J., 2012. Tectonic geomorphology: Landslides limit mountain relief. Nat. Geosci. 5, 446-447.

Sato, H.P., Harp, E.L., 2009. Interpretation of earthquake-induced landslides triggered by the 12 May 2008, M 7.9 Wenchuan earthquake in the Beichuan area, Sichuan Province, China using satellite imagery and Google Earth. Landslides 6, 153-159.

Sendir, H., Yilmaz, I., 2002. Structural, geomorphological and geomechanical aspects of the Koyulhisar landslides in the North Anatolian Fault Zone (Sivas, Turkey). Environ. Geol. 42, 52-60.

Shen, J., Yang,W., Liu, T., Huang, X., Zheng,W.,Wang, G., Yu, L., 2014. Micromorphology of quarze in the Bailong River fault gouge, West Qinling, China, and its chronological significance. Bull. Mineral. Petrol. Geochem. 33, 271-278 (in Chinese).

Si, H., Yang, W., Xie, S., Xiang, G., 2017. Deformation of Xieliupo landslide with consideration of time effect. J. Eng. Geol. 25, 463-471 (in Chinese).

Tang, C., Rengers, N., Van Asch, T.W.J., Yang, Y.H., Wang, G.F., 2011. Triggering conditions and depositional characteristics of a disastrous debris flow event in Zhouqu city, Gansu Province, northwestern China. Nat. Hazards Earth Syst. Sci. 11, 2903-2912.

Tarolli, P., Sofia, G., Fontana, G.D., 2012. Geomorphic features extraction from highresolution topography: landslide crowns and bank erosion. Nat. Hazards 61, 65-83.

Varnes, D.J., 1978. Slope movement types and processes. In: Schuster, R.L., Krizek, R.J. (Eds.), Landslides-Analysis and Control. Nat. Acad. Sci. Transport. Res. Board Spec vol. 176, pp. 11-33.

Wasowski, J., Bovenga, F., 2014. Investigating landslides and unstable slopes with satellite Multi Temporal Interferometry: current issues and future perspectives. Eng. Geol. 174, 103-138.

Whipple, K.X., Kirby, E., Brocklehurst, S.H., 1999. Geomorphic limits to climateinduced increases in topographic relief. Nature 401, 39-43.

Yang, W., Huang, X., Zhang, Y., Liu, T., 2013. The deformation characteristics of the landslide along Pingding-Huama active fault zone and its prevention and control. Geological Bulletin of China 32, 1925-1935 (in Chinese).

Yu, J., Zheng, W., Yuan, D., Pang, J., Liu, X., Liu, B., 2012. Late Quaternary active characteristics and slip-rate of Pingding-Huama fault, the eastern segment of Guanggaishan- Dieshan fault zone (West Qinling Moutain). Quaternary Sciences 32, 957-967 (in Chinese).

Yuan, D., Zhang, P., Liu, B., Gan, W., Mao, F., Wang, Z., Zheng, W., Guo, H., 2004. Geometrical imagery and tectonic transformation of late Quaternary active tectonics in northeastern margin of Qinghai-Xizang Plateau. Acta Geol. Sin. 78, 270-278 (in Chinese).

Zhang, G.W., Guo, A.L., Yao, A.P., 2004. Western Qinling-Songpan continental tectonic node in China's continental tectonics. Earth Science Frontiers 11, 23-32 (in Chinese).

Zhang, P.Z., Zheng, D.W., Yin, G.M., Yuan, D.Y., Zhang, G.L., Li, C.Y., Wang, Z.C., 2006. Discussion on late cenozoic growth and rise of northeastern margin of the 
772

Tibetan Plateau. Quaternary Sciences 26, 5-13 (in Chinese).

Zhang, K., Wang, G., Hong, H., Xu, Y., Wang, A., Cao, K., Luo, M., Ji, J., Xiao, G., Lin, X., 2013. The study of the Cenozoic uplift in the Tibetan Plateau: a review. Geological Bulletin of China 32, 1-18 (in Chinese).

Zhang, Y., Meng, X., Jordan, C., Novellino, A., Dijkstra, T., Chen, G., 2018. Investigating slow-moving landslides in the Zhouqu region of China using InSAR time series. Landslides 15, 1299-1315.

Zheng, W., Liu, X., Yu, J., Yuan, D., Zhang, P., Ge, W., Pang, J., Liu, B., 2016. Geometry and late Pleistocene slip rates of the Liangdang-Jiangluo fault in the western Qinling mountains, NW China. Tectonophysics 687, 1-13.

Table 1. Characteristics of landslides in the study area. The volume is calculated using the method of (Larsen, 2010): $\mathrm{V}=\alpha \mathrm{A}^{\gamma}$. For an accumulation layer landslide $\gamma=1.1-1.3$, and for a bedrock landslide $\gamma=1.3-1.6$. The landslides studied herein are accumulation layer landslides and therefore $\gamma=1.1-1.3$ is used. $\alpha=0.836 \pm 0.005$.

\begin{tabular}{ccccccc}
\hline Name & Area $\left(\mathbf{k m}^{2}\right)$ & Length $(\mathbf{m})$ & Height $(\mathbf{m})$ & Volume $\left(\mathbf{k m}^{3}\right)$ & Mean slope $\left({ }^{\circ}\right)$ & Aspect ratio \\
\hline $\begin{array}{c}\text { Average of } \\
\text { all landslides }\end{array}$ & 1.33 & 1745.6 & 680.8 & 1.3 & 27.2 & 2.8 \\
DL & 3.1 & 4617 & 1302.3 & 3.3 & 30.4 & 3.9 \\
XL & 2.0 & 3181 & 916.9 & 1.9 & 23.5 & 3.2 \\
YL & 1.2 & 2315 & 707.0 & 1 & 27.5 & 2.3 \\
ZL & 5.2 & 5118 & 1451.3 & 6.0 & 22.5 & 3.2 \\
\hline
\end{tabular}




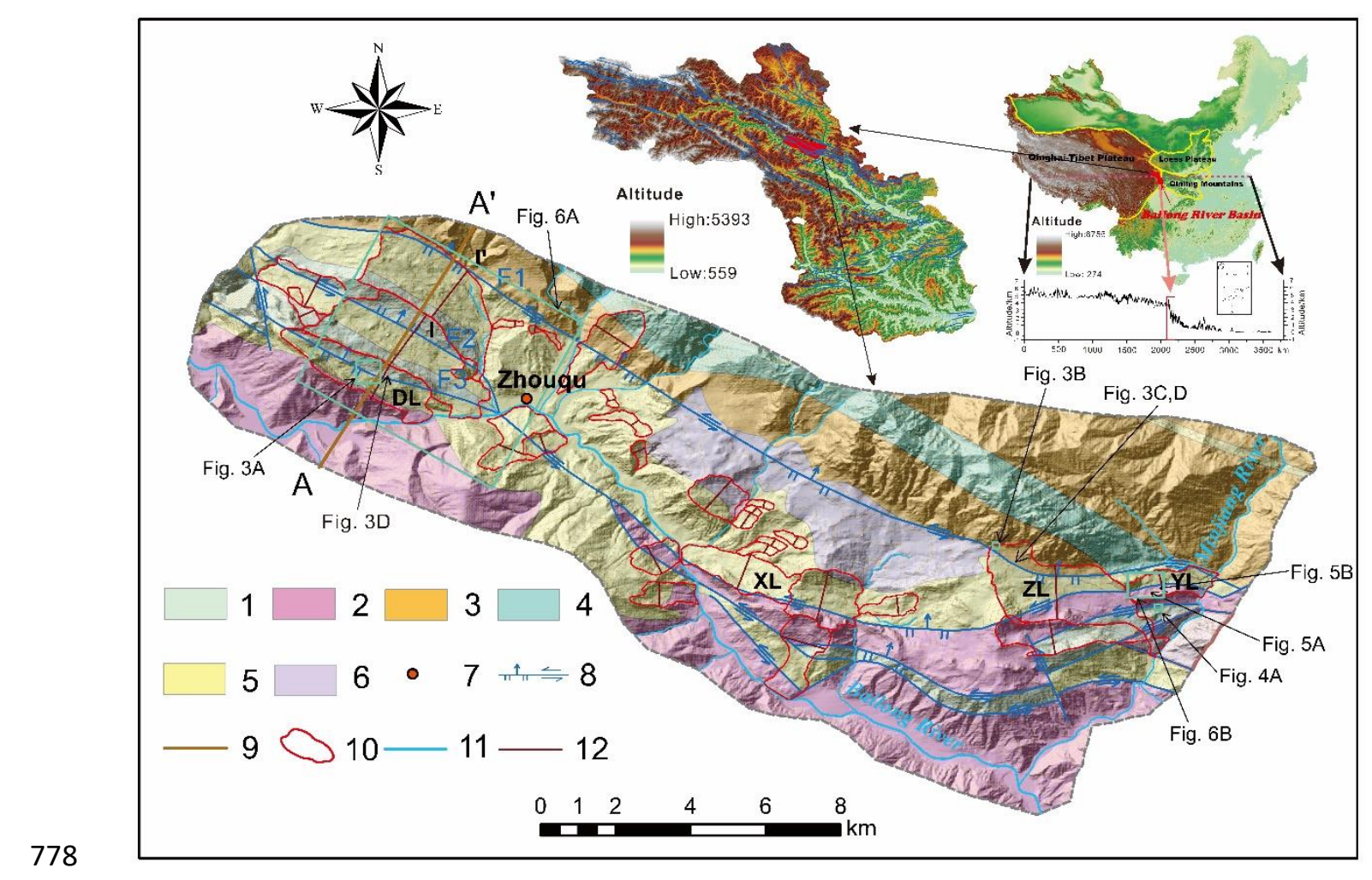

779 Fig. 1. Location of the study area in China, geology of the eastern Qinghai-Tibet Plateau, 780 and an inventory of landslides. 1. Early Carboniferous slate; 2. Middle-late Silurian 781 limestone; 3. Early Permian limestone; 4. Late Permian limestone; 5. Middle Devonian 782 slate (three fault fracture zones are developed); 6. Quaternary alluvial and proluvial 783 deposits; 7. County town; 8. Left-handed thrust fault; 9. Topographic cross section; 10. 784 Landslide boundary; 11. River; 12. Landslides cross section. 


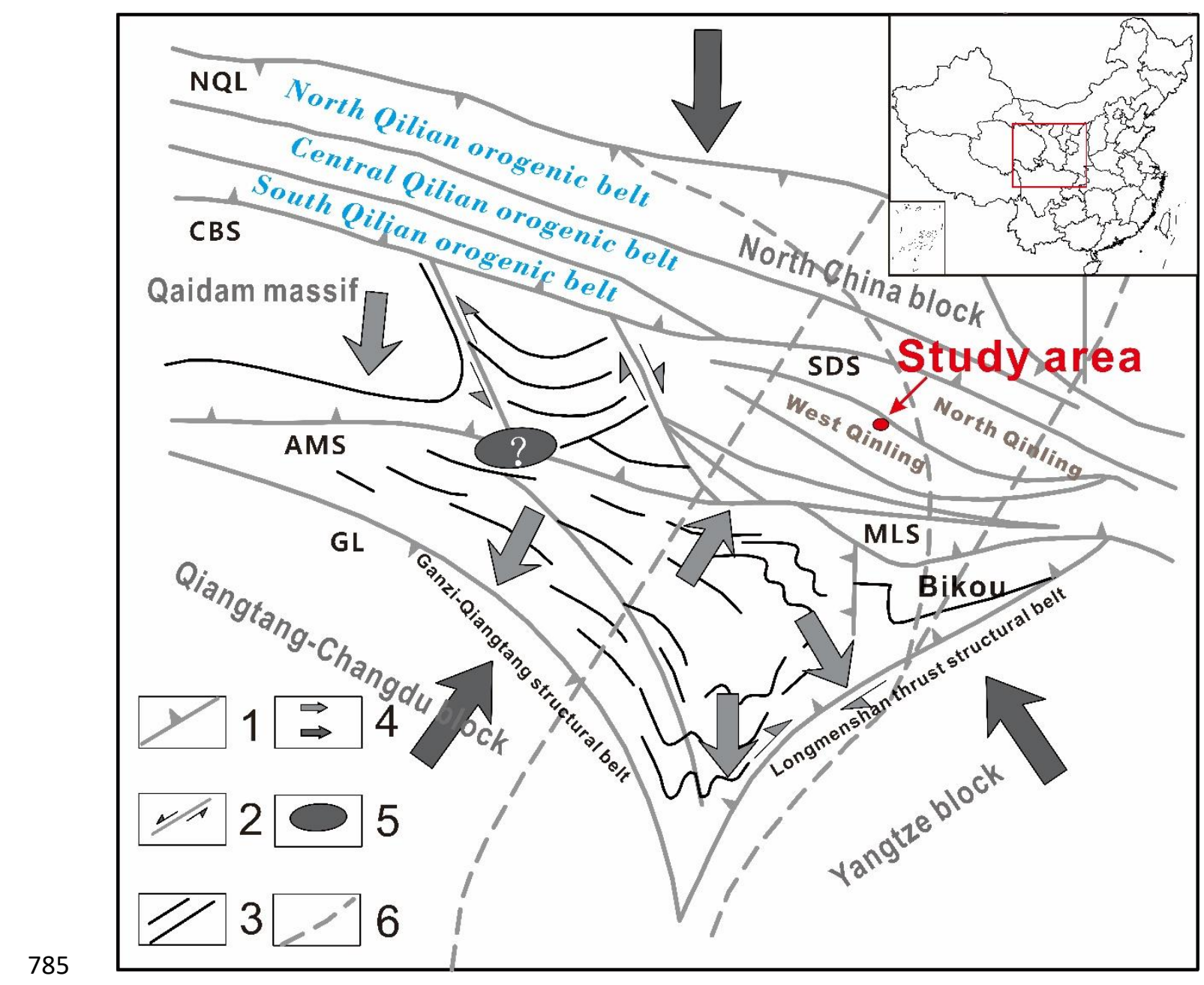

Fig. 2. Western Qinling-Songpan tectonic node. 1. Main faults (including ancient sutures) in structural junction areas. 2. Structural lines of the west Qinling and Gonghe aulacogen. 3. Main structural lines of the Songpan massif. 4. Main stress direction of the regional structure. 5. Possible hot spots and tri-junctions. 6. North-south structural belt of the Sichuan-Yunnan-Helan tectonic belt. CBS: Ancient suture belt of the northern margin of the Qaidam Basin; SDS: Shangdan ancient suture belt; KLS: ancient suture belt of East Kunlun; AMS: Anemaqen ancient suture belt; NQL: North Qilian suture belt; MLS: Mianlue ancient suture zone; GL: east-west boundary of the GanziLitang structural zone (after Zhang, 2004). 




796 Fig. 3. Field photo showing the role of gray-black fault gouge in slip surface 797 development. (Photo by Tianjun Qi.) 

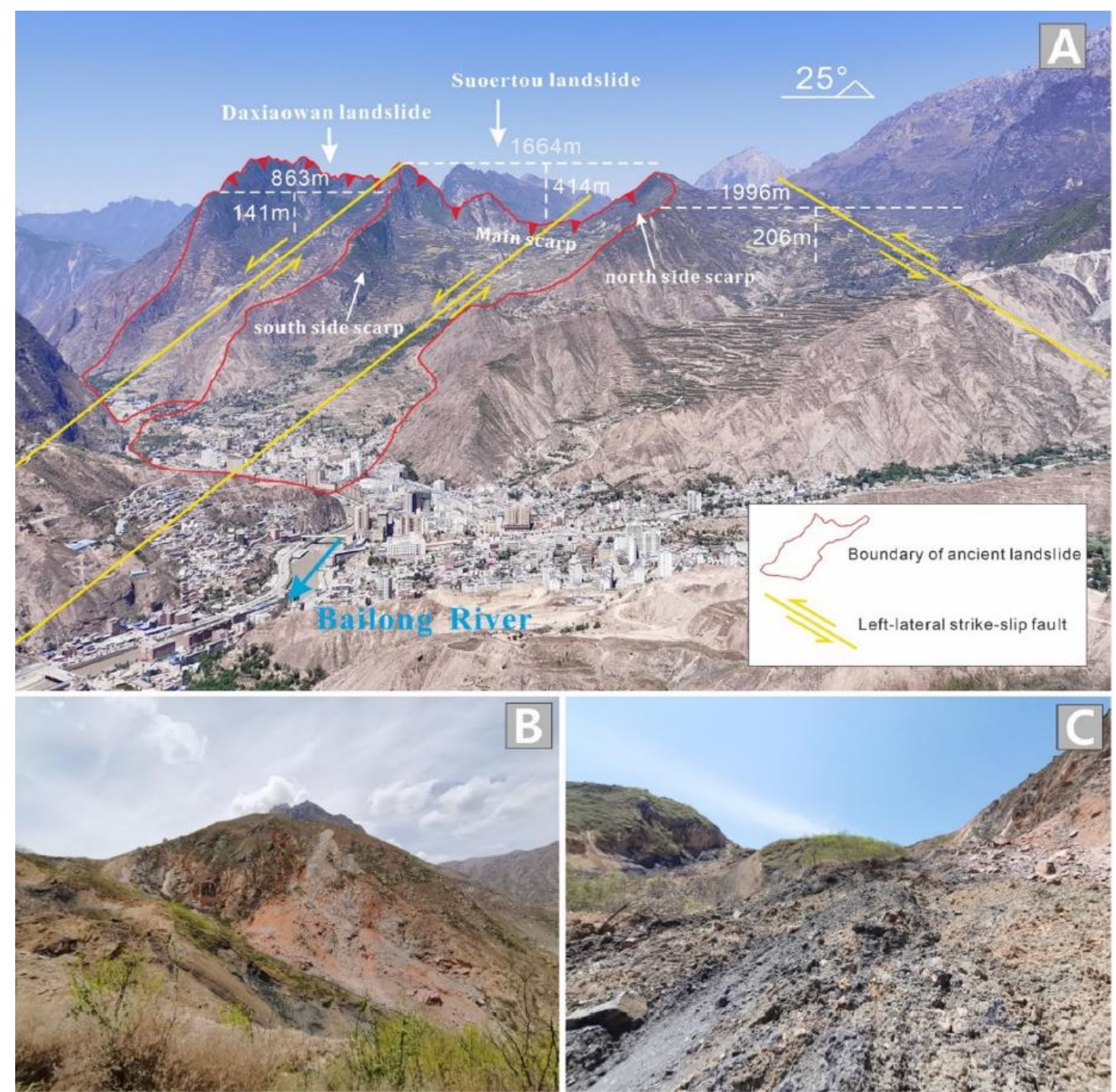

800 Fig. 4. A. Fault zone groove formed after erosion; the north scarp is flat and the south 801 scarp is high and steep with abundant rockfalls. B. The head of landslide YL (Figs. 1, 802 11A). C. Typical landslide mass in the fault zone with some degree of stratification. The 803 lower part is argillized slate, the upper part is covered with loess, and the two sides are 804 covered by in rockfalls. (Photo by Tianjun Qi.) 

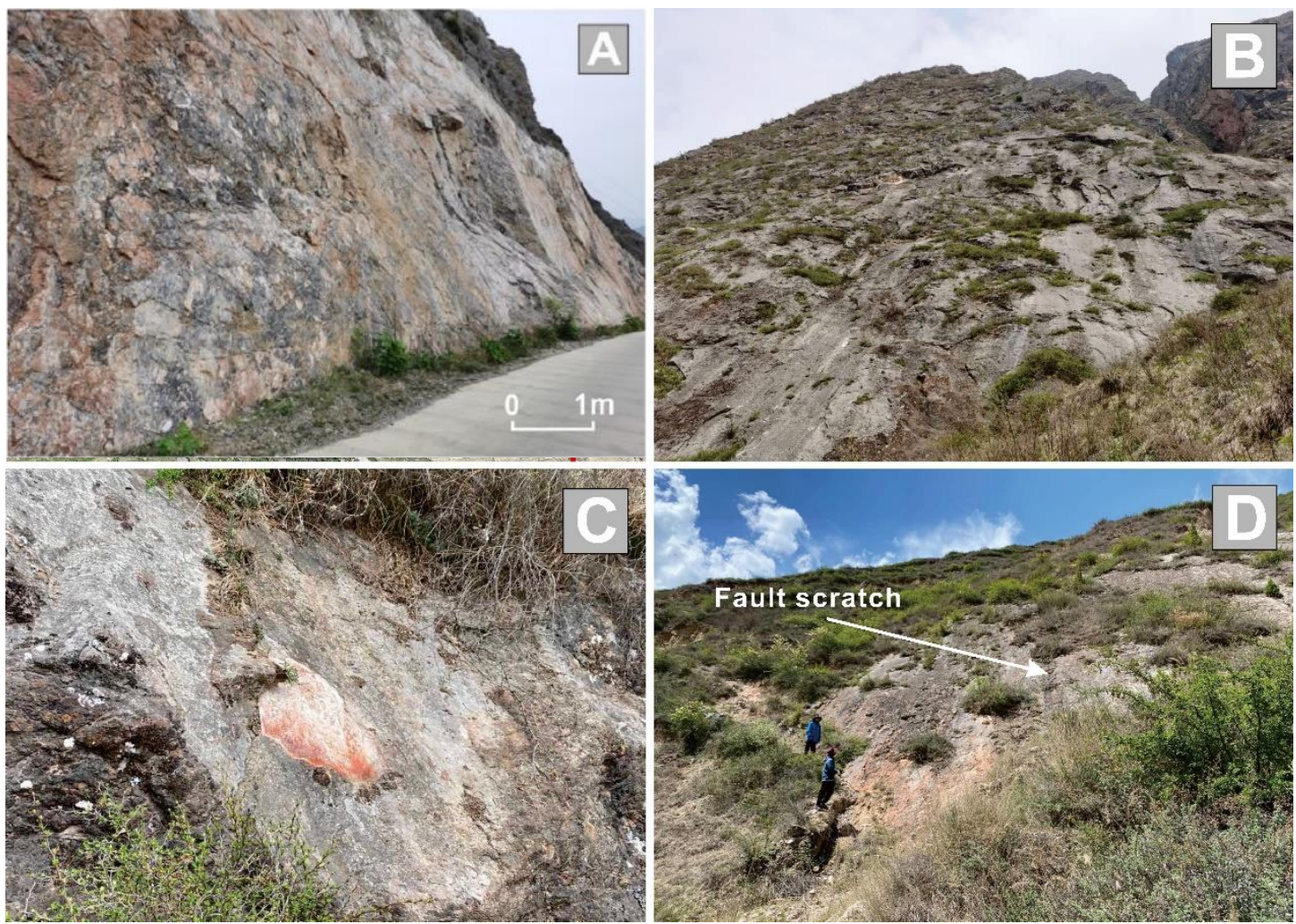

806 Fig. 5. Fault surfaces exposed in the study area. A. Bedding landslide developed on the 807 north scarp of landslide DL (Figs. 1, 7B); the sliding surface is the fault surface. B.

808 Fault triangle exposed on the north scarp of landslide ZL (Figs. 1, 7C). C. Fault surface 809 exposed on the north scarp of landslide ZL with fault scratches; D. Fault plane and 810 scratch developed in landslide DL. 

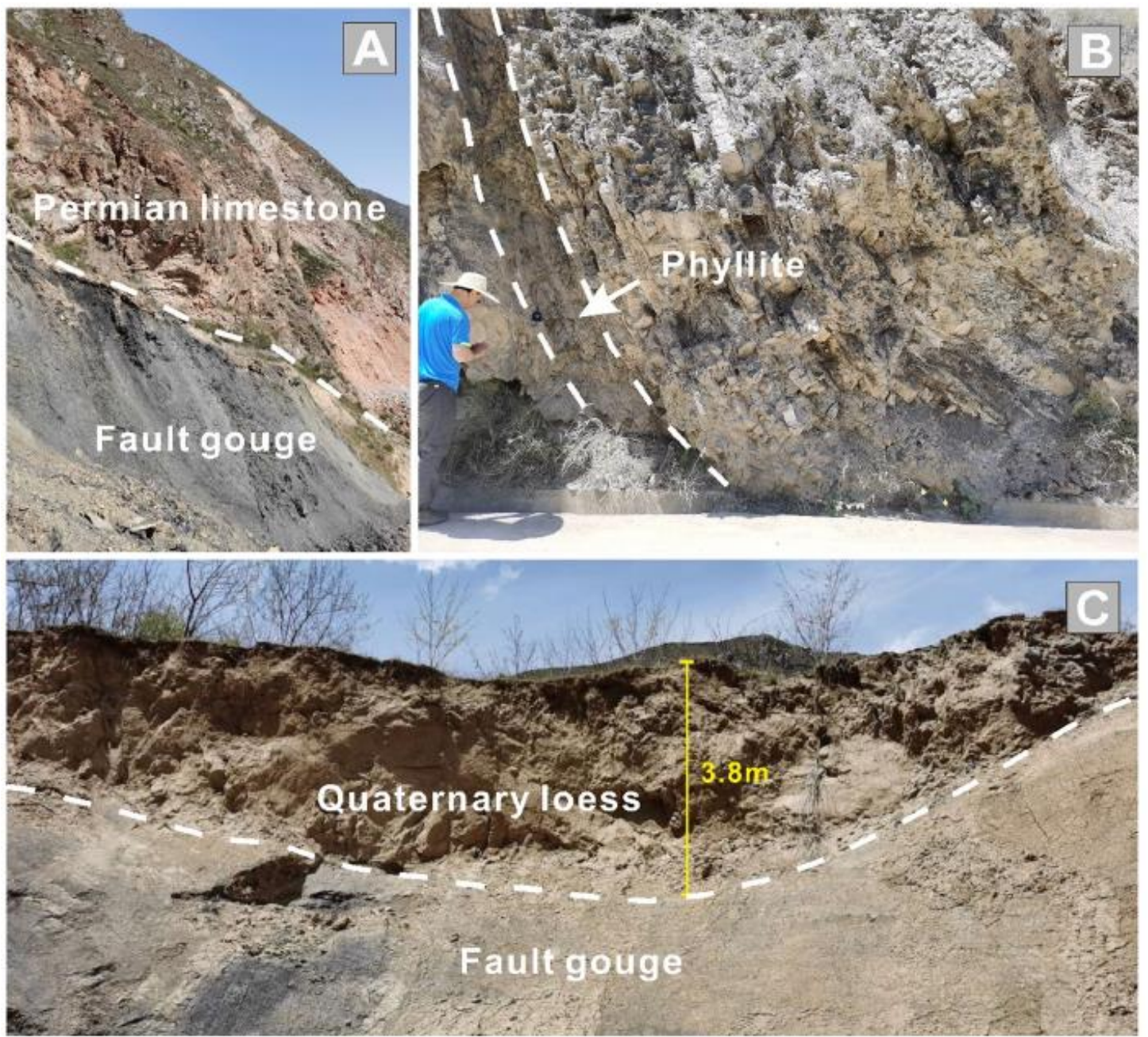

812 Fig. 6. A. The interface between Permian limestone and fault zone. B. Phyllite 813 intercalated within limestone. C. Quaternary loess overlying fault gouge. (Photo by 814 Tianjun Qi.) 

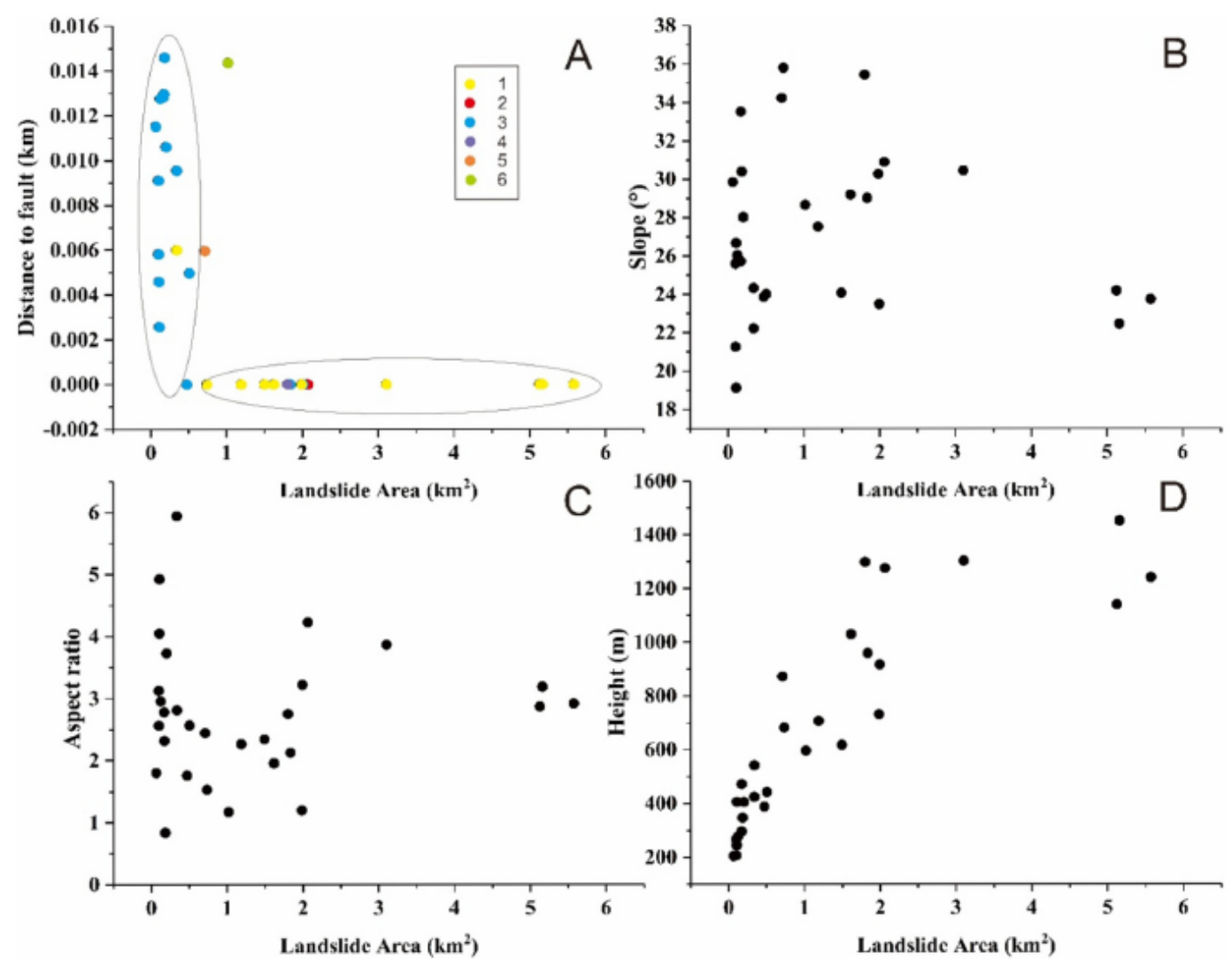

816 Fig. 7. Relationship between landslide area and (A) distance from landslide margin to

817 fault, the color represents different lithology of landslides, 1. Middle Devonian slate and Early Carboniferous slate; 2. Early Carboniferous slate; 3. Middle Devonian phyllite; 4. Permian limestone and Middle Devonian phyllite and slate; 5. Middle Devonian phyllite and slate and Quaternary alluvial and proluvial deposits; 6. Middle Devonian phyllite and slate and Middle-late Silurian limestone, (B) slope, (C) aspect ratio (length: width), (D) landslide height. 

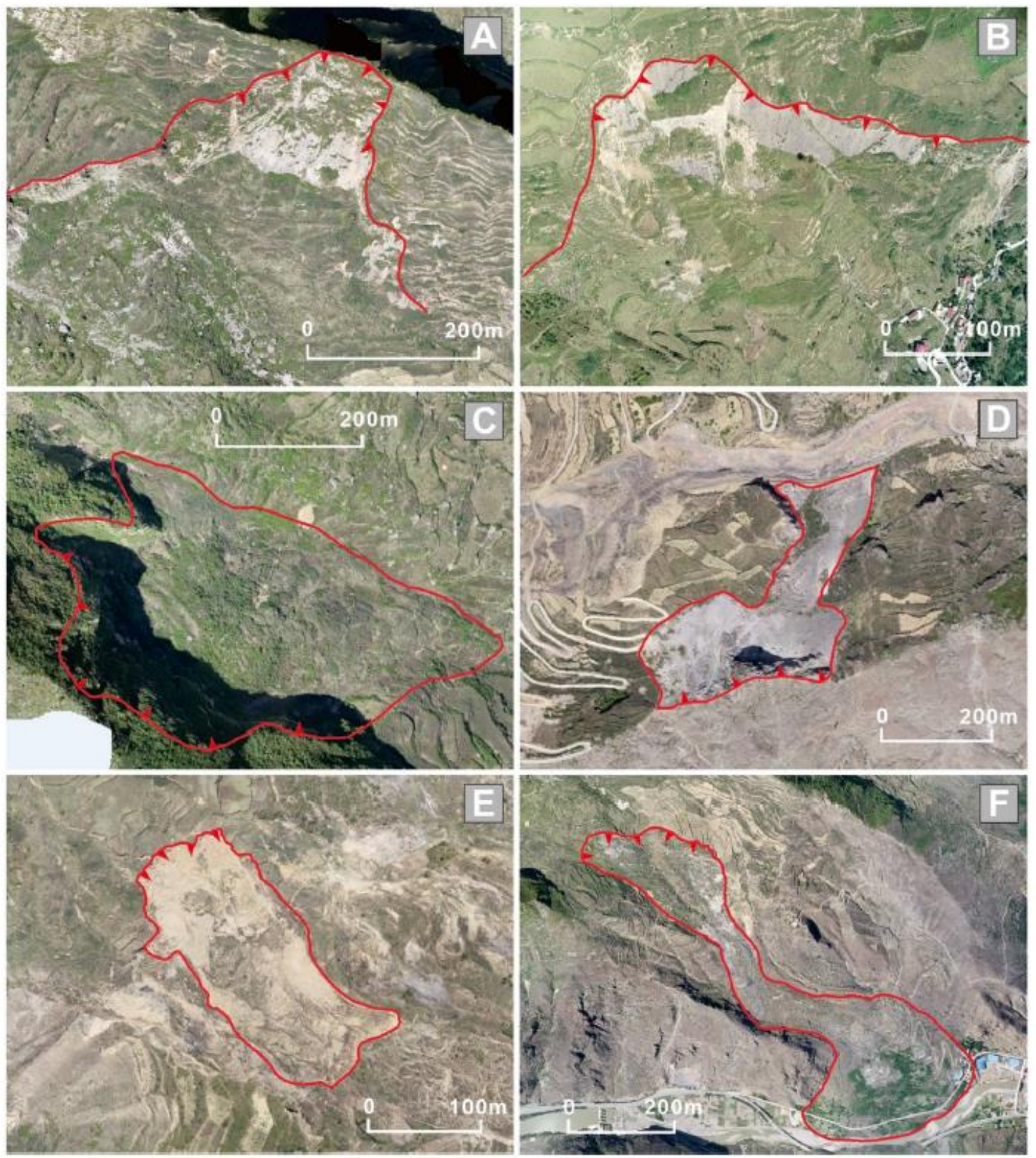

Fig. 8. The different types of secondary landslides on the complex landslide bodies.

825 A. Translational landslide developed on the north scarp of DL (Fig. 11B). B. Rock avalanche developed on the south scarp of DL. D. Rockfall developed on the south scarp of YL (Fig. 11A). E. Loess landslide developed on XL (Fig. 11B). F. Earthflow developed on DL. (Photo by Wei Shi.) 


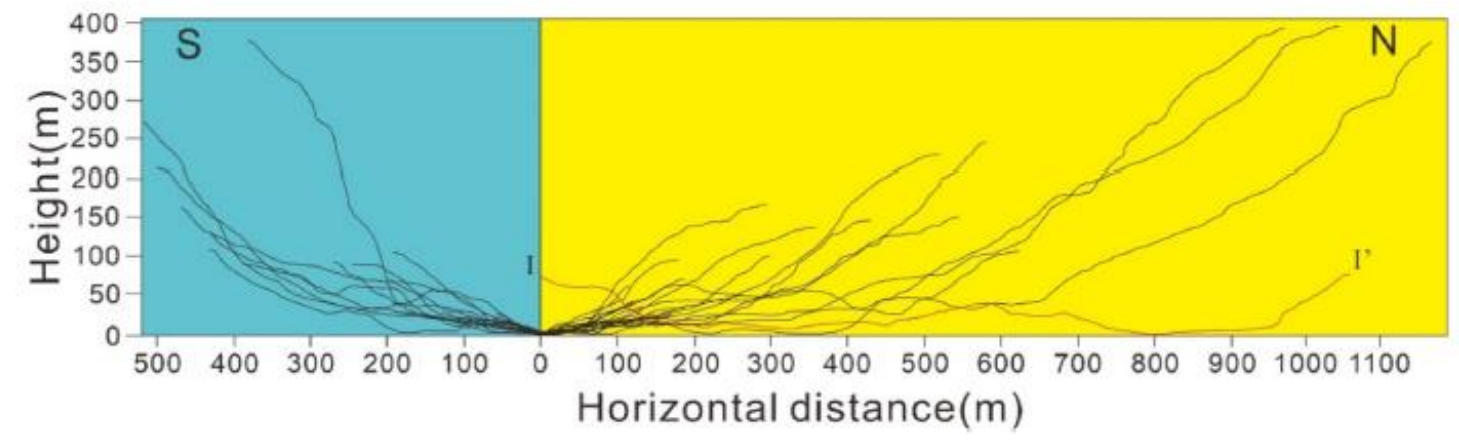

832 Fig. 9. Cross sections of 29 landslides in the study area. Except for cross section I-I', 833 the lowest point of the cross sections is located at the same position on the $\mathrm{x}$ axis.

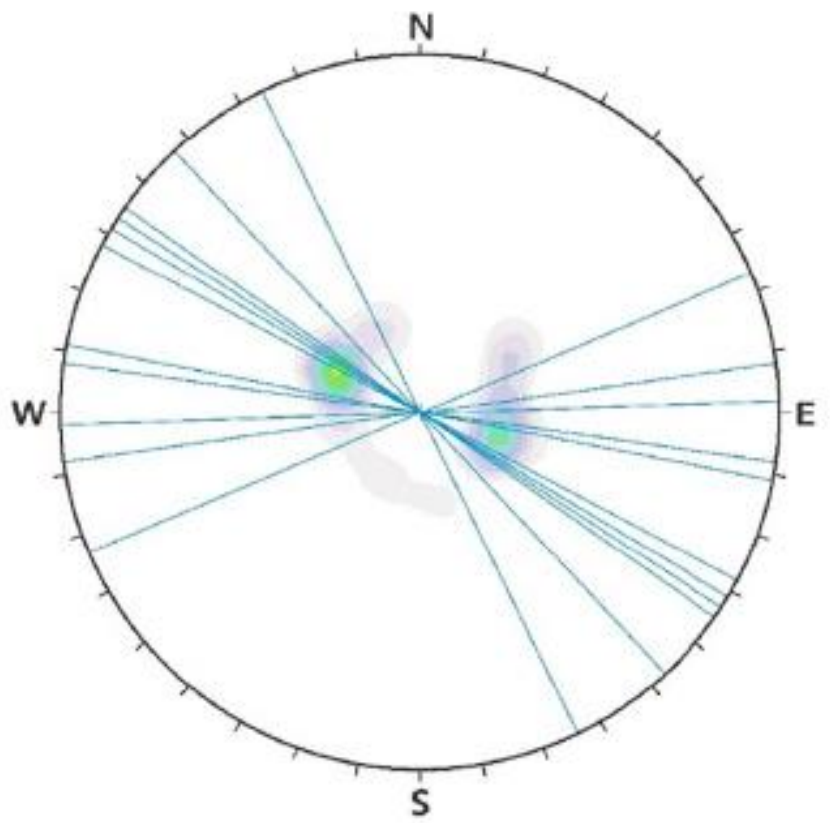

Fisher concentrations ( $\%$ of total per $1 \%$ of area)

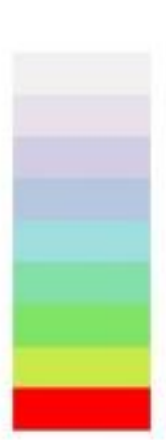

$$
\begin{array}{r}
0.00 \sim 3.00 \% \\
3.00 \sim 6.00 \% \\
6.00 \sim 9.00 \% \\
9.00 \sim 12.00 \% \\
12.00 \sim 15.00 \% \\
15.00 \sim 18.00 \% \\
18.00 \sim 21.00 \% \\
21.00 \sim 24.00 \% \\
24.00 \sim 27.00 \% \\
27.00 \sim 30.00 \%
\end{array}
$$

836 Fig. 10. The strike of faults in the study area and a contour map of landslide sliding direction and slope angle. 


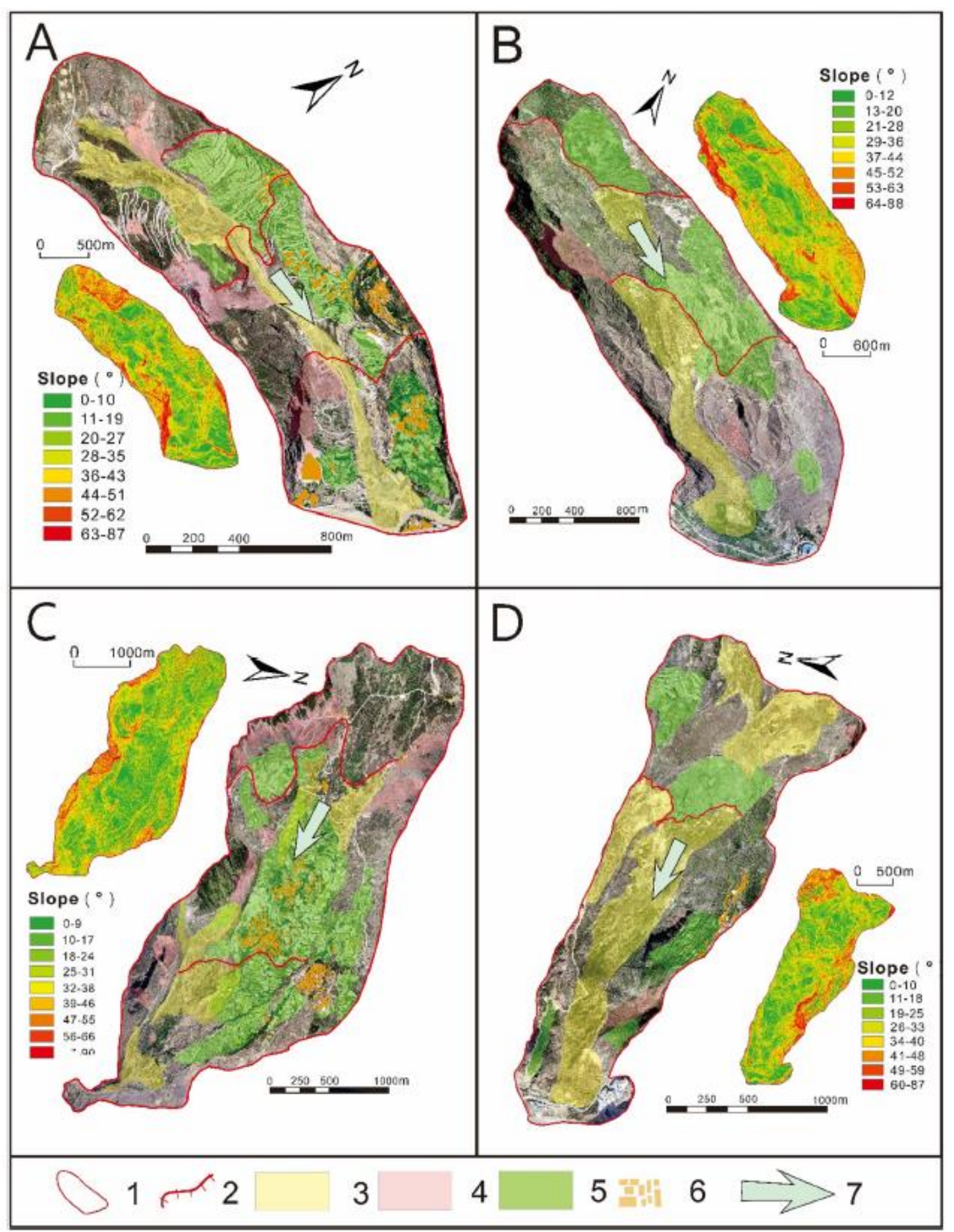

Fig. 11. Distribution of surface features of four typical landslides in the study area

842 based on UAV images. A. YL (Yahuokou landslide), B. DL (Daxiaowan landslide), C.

843 ZL (Zhongpai landslide), D. XL (Xieliupo landslide). 1. boundary of ancient

844 landslide; 2. scarp; 3. secondary earthflow; 4. rockfall; 5. farmland; 6. buildings; 7.

845 direction of landslide movement. 


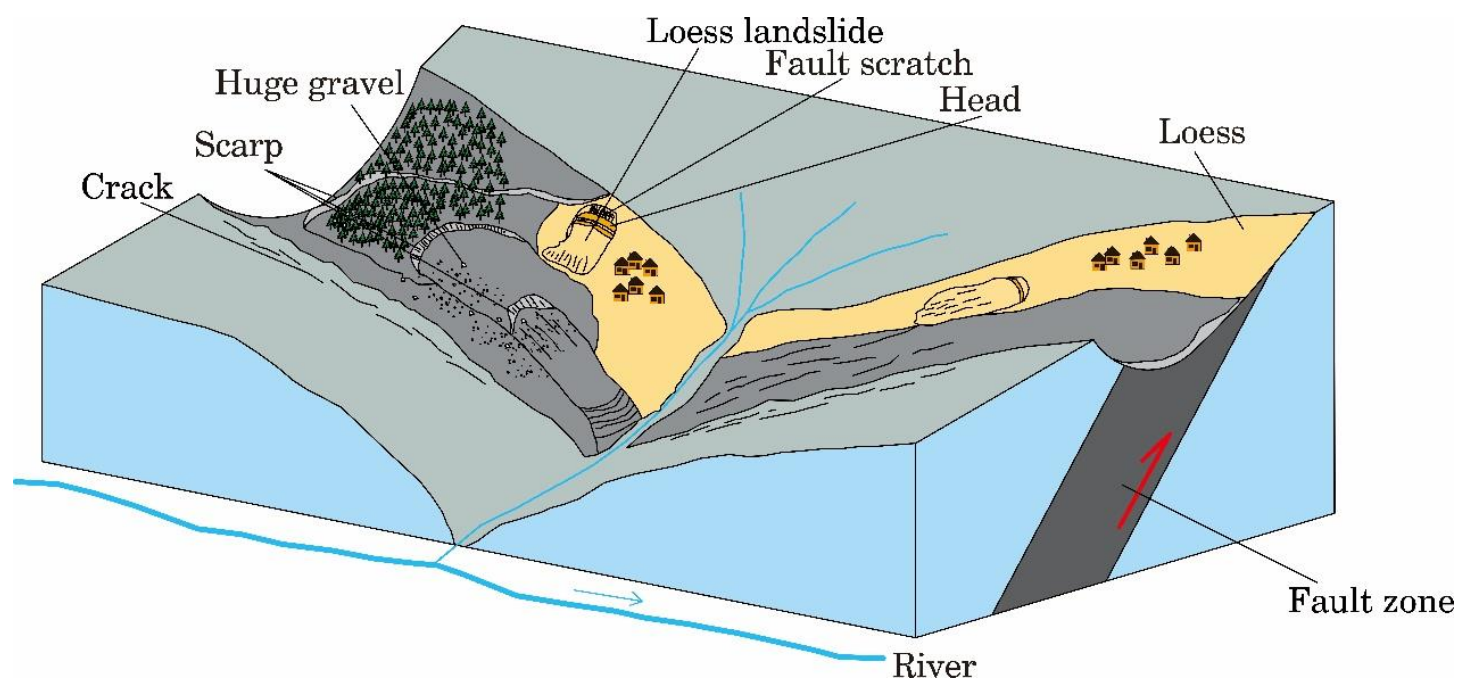

848 Fig. 12. Idealized three-dimensional representation of typical fault zone landslides in 849 the study area.

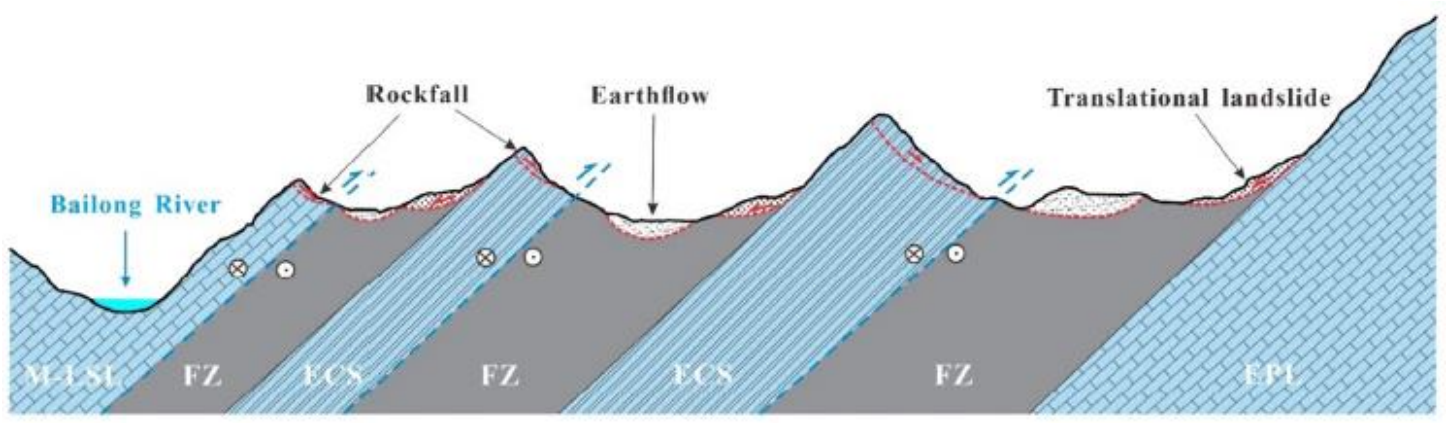

851 Fig. 13. Conceptual model of the development and evolution of large landslide 852 controlled by fault zone in the middle section of the Bailong River Basin. M-LSL:

853 Middle-late Silurian limestone, FZ: fault zone, ECS: Early Carboniferous slate, EPL:

854 Early Permian limestone. 